\title{
Virulence gene profiles of avian pathogenic Escherichia coli isolated from chickens with colibacillosis in Bulawayo, Zimbabwe
}

\author{
Authors: \\ Joshua Mbanga ${ }^{1}$ \\ Yvonne O. Nyararai ${ }^{1}$ \\ Affiliations: \\ ${ }^{1}$ Department of Applied \\ Biology and Biochemistry, \\ National University of \\ Science and Technology, \\ Zimbabwe \\ Correspondence to: \\ Joshua Mbanga \\ Email: \\ joshmbanga@gmail.com \\ Postal address: \\ PO Box AC 939, Ascot, \\ Bulawayo 00263, Zimbabwe \\ Dates: \\ Received: 15 July 2014 \\ Accepted: 15 Oct. 2014 \\ Published: 07 Apr. 2015 \\ How to cite this article: \\ Mbanga, J. \& Nyararai, \\ Y.O., 2015, 'Virulence gene \\ profiles of avian pathogenic \\ Escherichia coli isolated from \\ chickens with colibacillosis \\ in Bulawayo, Zimbabwe', \\ Onderstepoort Journal of \\ Veterinary Research 82(1), \\ Art. \#850, 8 pages. http:// \\ dx.doi.org/10.4102/ojvr. \\ v82i1.850

\section{Copyright:} \\ C 2015. The Authors. \\ Licensee: AOSIS \\ OpenJournals. This work is \\ licensed under the Creative \\ Commons Attribution \\ License.
}

\section{Read online:}

Scan this QR code with your smart phone or mobile device mobile device
to read online.
Colibacillosis, a disease caused by avian pathogenic Escherichia coli (APEC), is one of the main causes of economic losses in the poultry industry worldwide. This study was carried out in order to determine the APEC-associated virulence genes contained by E. coli isolates causing colibacillosis in chickens. A total of $45 \mathrm{E}$. coli isolates were obtained from the diagnostics and research branch of the Central Veterinary Laboratories, Bulawayo, Zimbabwe. These isolates were obtained from chickens with confirmed cases of colibacillosis after postmortem examination. The presence of the iut $A, h l y F$, ompT, frz, sitD, fimH, kpsM, sit $A, \operatorname{sop} B$, uvr $Y$, pstB and vat genes were investigated by multiplex polymerase chain reaction (PCR) assay. Of the 45 isolates, $93 \%$ were positive for the presence of at least one virulence gene. The three most prevalent virulence genes were iut A (80\%), fimH (33.3\%) and $h l y F(24.4 \%)$. The kpsM, pstB and omp $T$ genes had the lowest prevalence, having been detected in only $2.2 \%$ of the isolates. All 12 virulence genes studied were detected in the 45 APEC isolates. Virulence gene profiles were constructed for each APEC isolate from the multiplex data. The APEC isolates were profiled as $62.2 \%$ fitting profile A, $31.1 \%$ profile B and $6.7 \%$ profile $C$. None of the isolates had more than seven virulence genes. Virulence profiles of Zimbabwean APEC isolates are different from those previously reported. Zimbabwean APEC isolates appear to be less pathogenic and may rely on environmental factors and stress in hosts to establish infection.

\section{Introduction}

In chickens, colibacillosis refers to any local or systemic infection caused entirely or partially by Escherichia coli (Omer et al. 2010). Colibacillosis is economically important worldwide as it results in high morbidity and mortality of affected birds (Dho-Moulin \& Fairbrother 1999; Dziva \& Stephens 2008). The infection is generally initiated or enhanced by predisposing agents, such as mycoplasmal or viral infections and environmental factors (Dho-Moulin \& Fairbrother 1999). However, management approaches based only on protecting poultry against predisposing conditions have proved largely ineffective for controlling outbreaks of avian colibacillosis (Barnes, Nolan \& Vaillancourt 2008).

Antimicrobial drugs remain important in reducing both incidence and mortality associated with this disease (Zakeri \& Kashefi 2012) but there is increasing evidence that avian pathogenic E. coli (APEC) is becoming more resistant to antimicrobial agents (Saidi, Marifakureva \& Mbanga 2013; Sharada, Ruban \& Thiyageeswaran 2009; Skyberg et al. 2006). A vaccine based approach for the control of outbreaks of avian colibacillosis is therefore highly desirable (Olsen, Christensen \& Bisgaard 2012). Currently available vaccines are not totally effective (Schouler et al. 2012). This is mainly because of the diverse characteristics of APEC strains, which prevent the identification of common properties that could be used as a basis for vaccination (Schouler et al. 2012).

Several virulence factors have been associated with the virulence of APEC, including those encoding for adhesins, toxins, iron acquisition systems, autotransporters, sugar metabolism, serum resistance proteins, and capsule as well as lipopolysaccharide complexes (Ewers, Janssen \& Wieler 2003; Li et al. 2005; Schouler et al. 2012). However, numerous studies have demonstrated that these virulence factors are rarely all present in the same isolate and that they can occur either individually or polygenically with varying frequencies in clinical isolates (Delicato et al. 2003; Vandekerchove et al. 2005). This all indicates that APEC strains constitute a heterogeneous group. The accurate identification of virulent strains of E. coli and the virulence genes they possess is essential if genes that can serve as vaccine targets are to be identified. Virulence gene studies are therefore important as they not only aid in the characterisation of pathogenic strains of $E$. coli but may eventually lead to the development of effective vaccines. 
Work on virulence genes in the western world and most of Asia is on the rise, but in Africa very little information seems to be available (Randall et al. 2012; Van der Westhuizen \& Bragg 2012). In this study, 12 different APEC virulence genes were used to characterise Zimbabwean APEC isolates. The 12 genes used in this study included the iut $A, h l y F$, ompT, frz, sitD, fimH, kpsM, sit A, sopB, uvrY, pstB and vat genes (full names provided in Table 2). These have all been previously reported in literature, and some have been shown to occur in high frequencies in APEC isolates from other countries (Johnson et al. 2008; Kafshdouzan et al. 2013; Schouler et al. 2012). A number of studies have reported the successful use of multiplex polymerase chain reaction (PCR) in the detection of virulence genes in $E$. coli isolated from different organisms like dogs (Pass, Odedra \& Batt 2000), pigs (Schierack et al. 2006) and poultry (Ewers et al. 2005). This study used multiplex PCR developed by Van der Westhuizen and Bragg (2012) to detect virulence genes in APEC isolates. Virulence gene profiles were then constructed for each APEC isolate from the multiplex data. This study was carried out in order to provide information on the virulence factors of $E$. coli isolated from chickens with confirmed cases of colibacillosis in Zimbabwe.

\section{Materials and methods Sample collection}

All of the $45 \mathrm{E}$. coli isolates used in this study were obtained from the diagnostics and research branch of the Central Veterinary Laboratories, Bulawayo. These isolates were obtained from chickens with confirmed cases of colibacillosis after postmortem examination. Confirmatory tests were carried out on the isolates and the identification of E. coli was performed according to methods described by Barrow and Feltham (1993). Biochemical tests included the Gram stain and the catalase, oxidase, indole and citrate tests.

\section{DNA extraction}

Bacterial strains were subcultured overnight at $37^{\circ} \mathrm{C}$ in LuriaBertani (LB) broth (Oxoid, Basingstoke, Hampshire, UK) and genomic deoxyribonucleic acid (DNA) was extracted using a standard phenol-chloroform method (Sambrook \& Russell 2001). To check for purity, DNA was run along a $1 \%$ ethidium bromide-stained agarose gel (Sigma-Aldrich, St Louis, USA) with a $1 \mathrm{~kb}$ DNA ladder (Thermo Scientific, Waltman, Massachusetts, USA) in tris-borate-EDTA (TBE) buffer for $1 \mathrm{hr}$ at $100 \mathrm{~V}$ and then viewed using the Uvipro Silver Gel Documentation System (Uvitec, Cambridge, UK). The concentration of DNA was estimated by comparing the band light intensity to the band intensity on the $1 \mathrm{~kb}$ ladder on the Uvipro Silver Gel Documentation System. DNA concentration of samples ranged from $75 \mathrm{ng} / 0.5 \mu \mathrm{g}$ to $100 \mathrm{ng} / 0.5 \mu \mathrm{g}$.

\section{Virulence genotyping}

The presence of genes encoding virulence factors was detected using multiplex PCR amplification. Four multiplex PCR assays were used to detect 12 virulence genes (Table 1). The multiplex design was according to that reported by Van der Westhuizen and Bragg (2012), with slight changes in the primer and final magnesium chloride concentrations. The effected changes were using primer concentrations of $0.5 \mu \mathrm{M}$ for the frz, sitD, fim $H$, ompT, iut $A, p s t B$ and $s o p B$ genes and adjusting the final magnesium chloride $\left(\mathrm{MgCl}_{2}\right)$ concentration to $3 \mathrm{mM}$ for all multiplex reactions. The primers used in this study are listed in Table A1 in Appendix 1. All primers used were obtained from Inqaba Biotech, Pretoria, South Africa. Three microlitres of each of the DNA samples were mixed with all necessary components for amplification in a 0.2 mL PCR tube (Perkin-Elmer, Waltman, Massachusetts, USA) in a $25 \mu \mathrm{L}$ reaction. The reaction mixture included $2.5 \mu \mathrm{L}$ of $\times 10$ PCR Dream Taq buffer (Thermo Scientific, Waltman, Massachusetts, USA), $2 \mu \mathrm{L}$ of deoxynucleotide triphosphates (dNTPs) $10 \mathrm{mM} ; 0.25 \mu \mathrm{L}$ of Dream Taq polymerase (Thermo Scientific, Waltman, Massachusetts, USA), $5 \mathrm{U} / \mu \mathrm{L}$ nuclease-free water to maintain a total volume of $25 \mu \mathrm{L}$. The appropriate primers ranging from $0.5 \mu \mathrm{M}$ to $2 \mu \mathrm{M}$ were added and the $\mathrm{MgCl}_{2}$ concentration was adjusted to a final concentration of $3 \mathrm{mM}$, as shown in Table 1. Negative controls comprised a water control. An Applied Biosystems GeneAmp ${ }^{\circledR}$ PCR System 9700 was used for the PCR thermal cycling conditions with an initial denaturation step at $94{ }^{\circ} \mathrm{C}$ for $5 \mathrm{~min}$, 35 cycles (denaturation at $94{ }^{\circ} \mathrm{C}$ for $30 \mathrm{sec}$, annealing at $63{ }^{\circ} \mathrm{C}$ for $45 \mathrm{sec}$, extension at $72{ }^{\circ} \mathrm{C}$ for $1 \mathrm{~min}$ and $45 \mathrm{sec}$ ) and a final elongation step at $72{ }^{\circ} \mathrm{C}$ for $10 \mathrm{~min}$. The amplified products were then run along a $1 \%$ ethidium bromidestained agarose gel with a $100 \mathrm{bp}$ DNA ladder (Thermo Scientific, Waltman, Massachusetts, USA) in TBE buffer for $1 \mathrm{hr}$ at $100 \mathrm{~V}$ and then viewed using the Uvipro Silver Gel Documentation System (Uvitec, Cambridge, UK).

The multiplex PCRs described were used to screen for the presence of 12 virulence genes in the APEC isolates in duplicate. Prevalence of each virulence gene was calculated (Table 2) and virulence gene profiles were then assigned to each APEC isolate (Table 3).

TABLE 1: Final primer concentrations used in the different multiplex polymerase chain reactions.

\begin{tabular}{|c|c|c|c|c|c|c|c|c|}
\hline Multiplex & Primer set & Concentration $(\mu \mathrm{M})$ & Primer set & Concentration $(\mu \mathrm{M})$ & Primer set & Concentration $(\mu \mathrm{M})$ & Additional $\mathrm{MgCl}_{2}(\mathrm{mM})$ & Final $\mathrm{MgCl}_{2}(\mathrm{mM})$ \\
\hline 1 & $f r z$ & 0.5 & sitD & 0.5 & fimH & 0.5 & 1 & 3 \\
\hline 2 & sitA & 2.0 & kpsM & 1.0 & Vat & 0.5 & 1 & 3 \\
\hline 3 & ompT & 0.5 & iutA & 0.5 & pstB & 0.5 & 1 & 3 \\
\hline 4 & sop $B$ & 0.5 & uvrY & 1.0 & hlyF & 0.5 & 1 & 3 \\
\hline
\end{tabular}

$\mathrm{MgCl}_{2}$, Magnesium chloride. 
TABLE 2: Frequency of the 12 virulence genes in 45 avian pathogenic Escherichia coli isolates.

\begin{tabular}{lll}
\hline Name of gene & Primer name & Frequency (\%) \\
\hline Aerobactinsiderophore receptor & iutA & 80 \\
Type 1 fimbrial adhesin & fimH & 33.3 \\
Vacuolating autotransporter toxin & vat & 17.8 \\
SitABCD system & sitA & 11.1 \\
SitABCD system & sitD & 13.3 \\
Putative avian haemolysin & hlyF & 24.4 \\
PstSCAB system & pstB & 2.2 \\
frz operon & frz & 8.9 \\
APEC virulence regulator & uvrY & 4.4 \\
Capsule-protein transport of polysaccharides & kpsM & 2.2 \\
Episomal outer membrane protease & ompT & 2.2 \\
Plasmid partitioning protein & sopB & 20 \\
\hline
\end{tabular}

\section{Sequencing of polymerase chain reaction products to confirm amplification of the regions of interest}

Nine of the most prevalent genes (Table 2) were amplified using single PCR and $10 \mu \mathrm{L}$ of each sample was sent for sequencing at Inqaba Biotech, Pretoria, South Africa. PCR products were purified and concentrated by excising them from a $1 \%$ agarose gel using a sterile scalpel and then using a Zymo Research DNA clean and concentrator-5 kit(Epigenetics Company, Irvine, California, USA). Purification was carried out at the National University of Science and Technology (NUST). Sequencing was performed using an automated ABIPrism 3100 Genetic Analyser (Applied Biosystems, Foster

TABLE 3: Presence or absence of expected amplicons and virulence profiles of avian pathogenic Escherichia coli isolates.

\begin{tabular}{|c|c|c|c|c|c|c|c|c|c|c|c|c|c|c|}
\hline \multirow[t]{2}{*}{ Isolate } & \multicolumn{3}{|c|}{ Multiplex 1} & \multicolumn{3}{|c|}{ Multiplex 2} & \multicolumn{3}{|c|}{ Multiplex 3} & \multicolumn{3}{|c|}{ Multiplex 4} & \multirow[t]{2}{*}{ Total/12 } & \multirow{2}{*}{$\begin{array}{l}\text { Virulence } \\
\text { profile }\end{array}$} \\
\hline & $f r z$ & sitD & fimH & sitA & kpsM & vat & ompT & iutA & pstB & sopB & uvrY & hlyF & & \\
\hline$\overline{\text { CVL1 }}$ & - & - & - & - & - & - & - & - & - & - & - & - & 0 & $A \dagger$ \\
\hline CVL2 & - & - & - & - & - & - & - & - & - & + & - & + & 2 & A \\
\hline CVL3 & - & - & + & - & - & - & - & + & - & + & - & + & 4 & $B \neq$ \\
\hline CVL4 & - & - & - & - & - & - & - & + & - & + & - & + & 3 & B \\
\hline CVL5 & - & - & + & - & - & - & - & - & - & + & - & + & 3 & B \\
\hline CVL6 & - & - & + & - & - & - & - & + & - & + & - & + & 4 & B \\
\hline CVL7 & - & - & - & - & - & - & - & + & - & + & - & + & 3 & B \\
\hline CVL8 & - & - & - & - & - & - & - & + & - & - & - & - & 1 & A \\
\hline CVL9 & - & - & + & - & - & - & - & - & - & + & + & + & 4 & B \\
\hline CVL10 & - & - & - & - & - & - & - & - & - & + & - & + & 2 & A \\
\hline CVL11 & - & - & - & - & - & - & - & + & - & - & - & - & 1 & $A$ \\
\hline CVL12 & - & - & - & - & - & + & - & - & - & - & - & - & 1 & A \\
\hline CVL13 & - & - & - & - & - & - & - & + & - & - & - & - & 1 & A \\
\hline CVL14 & + & + & + & + & - & + & - & + & - & - & - & - & 6 & $C \S$ \\
\hline CVL16 & + & + & + & + & + & + & - & + & - & - & - & - & 7 & C \\
\hline CVL17 & - & + & + & + & - & + & - & + & - & - & - & - & 5 & B \\
\hline CVL18 & - & - & - & - & - & - & - & - & - & - & - & - & 0 & A \\
\hline CVL19 & - & - & + & - & - & - & - & + & - & - & - & - & 2 & A \\
\hline CVL20 & - & - & - & - & - & - & - & + & + & - & - & - & 2 & $A$ \\
\hline CVL21 & - & - & + & - & - & - & - & + & - & - & - & - & 2 & A \\
\hline CVL22 & - & - & + & - & - & - & - & + & - & - & - & - & 2 & A \\
\hline CVL23 & - & - & - & - & - & - & - & + & - & - & - & - & 1 & A \\
\hline CVL24 & - & - & - & - & - & - & - & + & - & - & - & - & 1 & A \\
\hline CVL25 & - & - & - & + & - & + & - & + & - & - & - & - & 3 & B \\
\hline CVL26 & - & - & - & - & - & - & - & - & - & - & - & - & 0 & A \\
\hline CVL27 & - & - & - & - & - & - & - & + & - & - & - & - & 1 & A \\
\hline CVL28 & - & - & - & - & - & + & - & + & - & - & - & - & 2 & A \\
\hline CVL29 & - & - & - & - & - & - & - & + & - & + & - & + & 3 & B \\
\hline CVL30 & - & - & - & - & - & + & - & - & - & - & - & - & 1 & A \\
\hline CVL33 & - & - & - & - & - & - & - & + & - & - & - & - & 1 & A \\
\hline CVL34 & - & + & + & - & - & - & - & + & - & - & - & - & 3 & B \\
\hline CVL35 & - & - & - & - & - & - & - & + & - & - & - & - & 1 & A \\
\hline CVL36 & + & - & + & - & - & - & - & + & - & - & - & - & 3 & B \\
\hline CVL37 & - & - & - & - & - & - & + & + & - & - & - & + & 3 & B \\
\hline CVL38 & - & - & - & - & - & - & - & + & - & - & - & - & 1 & A \\
\hline CVL39 & - & - & - & - & - & - & - & + & - & - & - & + & 2 & $A$ \\
\hline CVL40 & - & - & - & - & - & - & - & + & - & - & - & - & 1 & A \\
\hline CVL41 & - & + & + & - & - & - & - & + & - & - & - & - & 3 & B \\
\hline CVL42 & - & - & - & - & - & - & - & + & - & - & - & - & 1 & A \\
\hline CVL43 & - & - & + & - & - & - & - & + & - & - & + & - & 3 & B \\
\hline CVL44 & - & - & - & - & - & - & - & + & - & - & - & - & 1 & $A$ \\
\hline CVL45 & - & - & - & - & - & - & - & + & - & - & - & - & 1 & A \\
\hline
\end{tabular}

CVL, Central Veterinary Laboratories isolate obtained from confirmed case of colibacillosis.

+ , Presence of the expected amplicon during multiplex polymerase chain reaction; - , absence of the expected amplicon during multiplex polymerase chain reaction; $\dagger$, virulence profile $A$ indicates presence of 0 to 2 virulence genes; $\$$, virulence profile B indicates presence of 3 to 5 virulence genes; $\S$, virulence profile $C$ indicates presence of 6 or more virulence genes. 
City, USA) according to the manufacturer's instructions. DNA sequence data (chromatographs and sequences) were sent back by email for analysis. Sequence results were analysed using Basic Local Alignment Search Tool (BLAST) in the National Centre for Biotechnology Information (NCBI) databases to confirm the identity of the amplified regions.

\section{Results}

\section{Escherichia coli virulence gene screening}

All 45 isolates obtained from the Central Veterinary Laboratories (CVL), Bulawayo were positively identified and confirmed to be $E$. coli through culturing and biochemical tests. After successful DNA isolation and quantification, the DNA of each of the 45 APEC isolates was subjected to four different multiplex PCRs. Each multiplex reaction amplified three APEC virulence gene regions. This was done in order to screen the APEC isolates for 12 virulence associated genes. Figure 1 shows results for multiplex 1 , which targeted the $f r z$, sit $D$ and fim $H$ virulence genes. Some of the APEC isolates (14, 15 and 16) had all three genes present (Figure 1). Multiplex 2 targeted the $k p s M$, sit $A$ and vat virulence genes. Only one isolate (isolate 16) had all three genes, whilst isolates 12, 28 and 30 only had the vat gene (Figure 2). Figure 3 shows results for multiplex 3 , which assayed for the presence of the ompT, iut $A$ and $p s t B$ genes. Most of the APEC isolates had a $302 \mathrm{bp}$ amplicon consistent with the iut $A$ gene. Multiplex 4 assayed for the presence of the $\operatorname{sop} B, u v r Y$ and $h l y F$ virulence genes. Figure 4 shows the amplification of two bands $450 \mathrm{bp}$

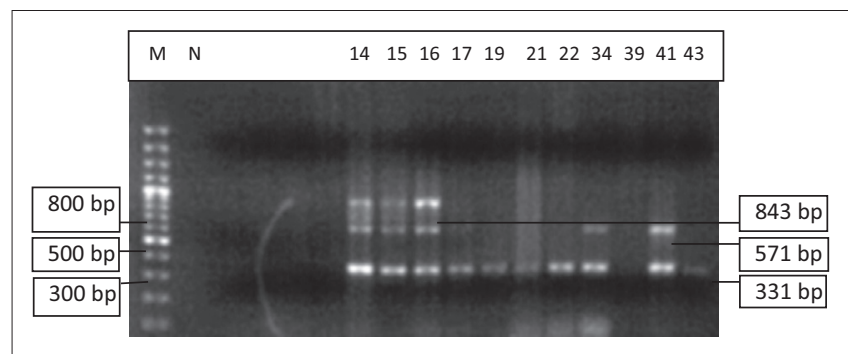

Note: Other lanes show results of multiplex PCR for isolates $14-43$ with variations in presence of virulence genes fimH (331 bp), sitD (571 bp) and frz (843 bp).

FIGURE 1: Multiplex 1. Lane $M$ indicates the lane containing the marker, GeneRuler 100 bp Plus DNA Ladder (Thermo Scientific, Waltham, Massachusetts, USA), whilst lane $\mathrm{N}$ indicates the negative control.

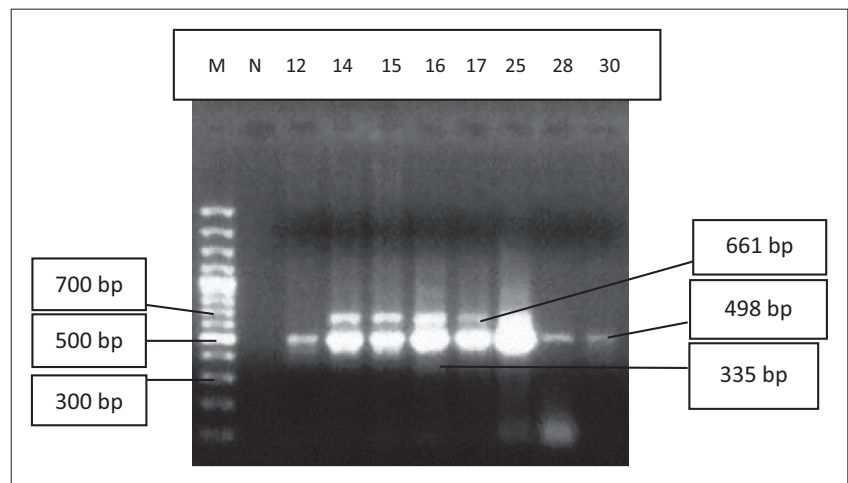

Note: Both vat (498 bp) and sitA (661 bp) were present in APEC isolates 14, 15, 16, 17 and 25 , whilst isolates 12,28 and 30 only had the vat gene.

FIGURE 2: Multiplex 2. Lane $M$ indicates the lane containing the marker, GeneRuler 100 bp Plus DNA Ladder (Thermo Scientific, Waltham, Massachusetts, USA) whilst lane $\mathrm{N}$ indicates the negative control.
(hlyF) and $797 \mathrm{bp}(\mathrm{sopB})$ for isolates 2, 3, 4, 5 and 7 and only one band $(450 \mathrm{bp})$ for isolate 6 . The most prevalent virulence associated genes in the APEC isolates tested were the iut $A$ gene $(80 \%)$, fimH (33.3\%), hlyF (24.4\%) and sopB (20\%) (Table 2). The data obtained from electrophoresis agarose gels were used to assign virulence gene profiles to each APEC isolate (Table 3).

\section{Single polymerase chain reactions and sequencing}

Nine of the most prevalent genes were successfully amplified using single PCR and produced the predicted sized bands during electrophoresis. To further confirm the identity of the amplicons, the bands obtained through electrophoresis were purified, concentrated and sent for sequencing. The sequences obtained (data not shown) were analysed using BLASTn and BLASTx and the amplicons were confirmed to be part of the genes of interest (data not shown).

\section{Discussion}

In this study, 45 E. coli isolates were obtained from chickens with confirmed cases of colibacillosis and screened for 12 virulence genes commonly associated with pathogenicity in APEC. Some of the virulence factors investigated have only been discovered recently. Ninety-three percent of the E. coli isolates in this study had at least one virulence

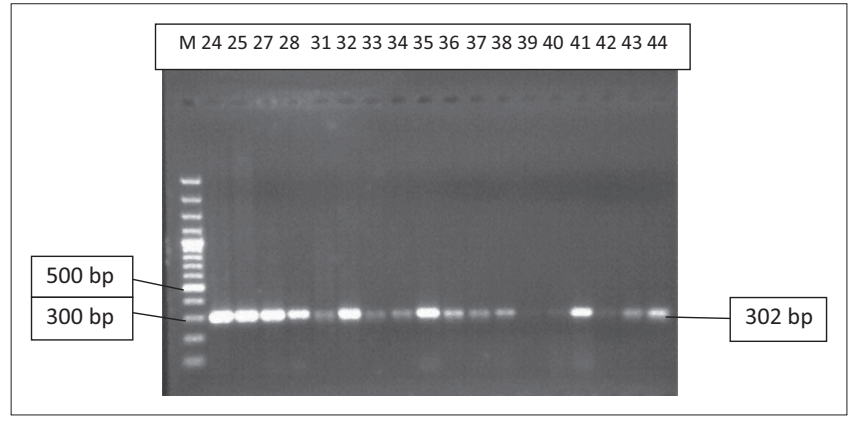

FIGURE 3: Multiplex 3. Lane $M$ indicates the lane containing the marker GeneRuler 100 bp Plus DNA Ladder (Thermo Scientific, Waltham, Massachusetts, USA). Isolates 24-44 all had the iutA (302 bp) gene.

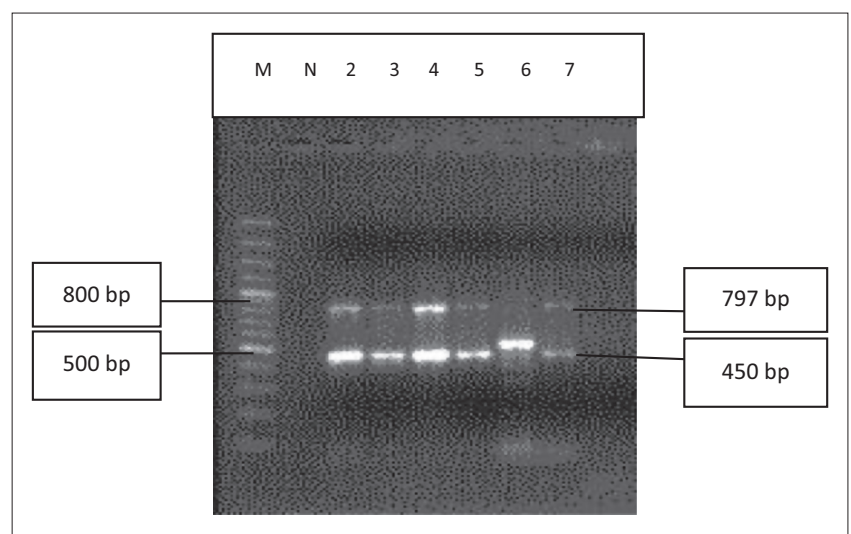

Note: APEC isolates 2, 3, 4, 5, 7 show presence of $h l y F(450 \mathrm{bp})$ and sopB (797 bp) genes. Isolate 6 only had the hlyF gene.

FIGURE 4: Multiplex 4. Lane $M$ indicates the lane containing the marker, GeneRuler 100 bp Plus DNA Ladder (Thermo Scientific, Waltham, Massachusetts, USA) whilst lane $\mathrm{N}$ indicates the negative control. 
gene, suggesting that the isolates used could have been APEC.

The iutA gene had the highest prevalence at $80 \%$ (Table 2). This gene has been well characterised and is one of the five genes of the aerobactin operon. It encodes an outer membrane protein involved in the high-affinity binding of $\mathrm{Fe}^{3-a e r o b a c t i n}$ and can be plasmid located (Johnson et al. 2006) or chromosomally encoded in some APEC strains (Schouler et al. 2012). The aerobactin system plays a role in the persistence and generation of lesions in APEC-infected chickens. The present findings are in agreement with other studies that found an equally high prevalence of the iutA gene in APEC isolates. These include the studies of Rodriguez-Siek et al. (2005), Johnson et al. (2008), and Schouler et al. (2012), who found prevalence rates of $80.2 \%$, $80.8 \%$ and $82.7 \%$ respectively. The Type 1 fimbrial adhesion gene $(\mathrm{fimH})$ had a prevalence of $33.3 \%$ in this study. Fim $H$ is thought to contribute to the protection of E. coli from host heterophils (Mellata et al. 2003). Its role in the virulence of APEC strains remains controversial, with conflicting reports (Li et al. 2005). Other studies have found higher occurrences of the fim $\mathrm{H}$ gene, notably that of RodriguezSiek et al. (2005), who found a prevalence of $98.1 \%$ for this gene in 524 APEC isolates. Interestingly, in a study by Van der Westhuizen and Bragg (2012) using 10 Zimbabwean APEC isolates, all 10 had the fimH gene present. The hlyF gene has been shown to contribute to iron uptake (Morales et al. 2004; Williams \& Warner 1980). HlyF has been well documented in chickens suffering from colibacillosis (Van der Westhuizen \& Bragg 2012). The hlyF gene had a prevalence rate of $24.4 \%$ in the current study (Table 2). This disagrees with several studies that have found higher prevalence rates (Johnson et al. 2008; Kafshdouzan et al. 2013). Another study, however, found a lower prevalence rate of a related gene, hlyE (Jin et al. 2008). The plasmid partitioning protein encoded by sopB is common in various plasmids associated with virulence characteristics in APEC (Van der Westhuizen \& Bragg 2012). The sopB gene had a prevalence rate of $20 \%$, which agrees with results from the study carried out on 10 Zimbabwean APEC isolates by Van der Westhuizen and Bragg (2012), as 30\% of their isolates had the $\operatorname{sop} B$ gene. The vacuolating autotransporter toxin (vat) gene, which has been shown to induce cytotoxic effects in host cells (Parreira \& Gyles 2003), was present in $17.8 \%$ of the isolates. This low prevalence rate agrees with other studies, in which detection rates of 39.8\% (Ewers et al. 2007), 25.5\% (Jin et al. 2008) and 33.4\% (Johnson et al. 2008) were found in APEC. The sit $A$ and sitD genes are part of the sit $A B C D$ system. Gene sit $A$ encodes a periplasmic binding protein of the sit $A B C D$ transport system, which is involved in iron and manganese transport and can be both chromosomally and plasmid located (Mellata, Touchman \& Curtiss 2009; Sabri, Léveillé \& Dozois 2006; Schouler et al. 2004). Sit $A B C D$ has been shown to play a role in virulence (Sabri et al. 2008). The prevalence of the sitA (11.1\%) and sitD (13.3\%) genes (Table 2$)$ is comparable to that found by Van der Westhuizen and Bragg (2012) but differs from those reported by Schouler et al. (2012) and Johnson et al. (2008) for the sitA gene and by Ewers et al. (2007) for the sit $B$ gene. The presence of these two genes agrees with the results of other scholars who believe that in $E$. coli sit $A B C D$-encoding genes are associated with clinical strains isolated from extra-intestinal infections from poultry and human urinary tract infections (RodriguezSiek et al. 2005; Schouler et al. 2004). The frz operon was present in $8.9 \%$ of the E.coli isolates (Table 2). Work by Rouquet et al. (2009) suggested that the gene products from the frz operon are used by E.coli to promote growth in serum during oxygen-restricted conditions. A link between the expression of this locus and E. coli pathogenic abilities was confirmed by experiments showing its role in promoting bacterial fitness under stressful conditions, including oxygen restriction or the late stationary phase of growth, and in promoting growth in chicken serum or the intestinal tract during in vivo competition assays (Schouler et al. 2012). The results of this study agree with those of Van der Westhuizen and Bragg (2012) with regard to the Zimbabwean isolates they worked on; however, they differ from work carried out by Schouler et al. (2012) in which they found a prevalence of $53.4 \%$ for the frz operon in 352 APEC isolates.

A transcriptional regulator of iron uptake genes in APEC, uvrY (Li et al. 2005) has only recently been used to screen for APEC using multiplex PCR (Van der Westhuizen \& Bragg 2012). In this study, this gene had a low prevalence rate of $4.4 \%$ (Table 2). This differs from the $100 \%$ reported by Van der Westhuizen and Bragg (2012) for the 10 Zimbabwean isolates they studied. The ompT, pstB and $k p s M$ genes all had a low prevalence rate of $2.2 \%$. The $o m p T$ gene encodes the episomal outer membrane protease that cleaves colicins (Cavard \& Lazdunski 1990). Other studies on APEC have shown higher detection rates of this gene (Johnson et al. 2008; Kafshdouzan et al. 2013; Rodriguez-Siek et al. 2005). The kpsM gene encodes proteins required for translocation of E. coli group II capsular polysaccharide across the inner membrane (Clarke, Pearce \& Roberts 1999). Prevalence rates of the $k p s M$ gene reported for APEC isolates have tended to be low: 15.7\% (Johnson et al. 2008), 15.8\% (RodriguezSiek et al. 2005) and 0\% for Zimbabwean isolates (Van der Westhuizen \& Bragg 2012). The $p s t B$ gene, which is part of the $p s t S C A B$ operon, has been shown to increase resistance to polymyxin, rabbit serum and acid shock (Lamarche et al. 2005). The $p s t B$ gene contributes to virulence but is still relatively new in the diagnostic context (Lamarche et al. 2005). As a result very little has been published on this virulence gene in APEC.

Virulence profiles were generated for each $E$. coli isolate used in this study (Table 3). The APEC isolates were profiled as $62.2 \%$ fitting profile $\mathrm{A}, 31.1 \%$ profile $\mathrm{B}$ and $6.7 \%$ profile C. None of the isolates had more than seven virulence genes. These findings agree with those of Van der Westhuizen and Bragg (2012). They found the Zimbabwean APEC isolates to have fewer virulence genes (with most having less than 
11/18 virulence genes studied) than the South African APEC isolates, which all had between 12 and 18 virulence genes. The low number of virulence genes in the isolates assayed in this study could be a result of the fact that these isolates possess other virulence genes that were not screened for. Numerous studies have demonstrated that virulence genes are rarely all present in the same isolate. Different isolates may harbour different associations of virulence genes and belong to specific subpathotypes, with each subpathotype characterised by the type of lesions it produces in poultry with avian colibacillosis (Maturana et al. 2011; Olsen et al. 2012). Another possibility is that the isolates used in this study belong to strains that are not highly pathogenic and that environmental or other disease factors caused stress in the hosts, which allowed them to be infected and led to colibacillosis (Van der Westhuizen \& Bragg 2012). The risk for colibacillosis is known to increase with increasing infection pressure in the environment. Good housing, hygiene and avoiding overcrowding are very important in reducing infection rates (Saidi et al. 2013). Another reason, although less likely, could be that the strains used in this study were not the causative agents in the confirmed colibacillosis cases. This is because isolation of an E. coli strain from a pathological lesion is not a sufficient criterion to classify it as a pathogen (Schouler et al. 2012).

\section{Limitations}

Potential biases in this study are related to the relatively small sample size of $E$. coli isolates used. In addition, in vivo tests of the isolates to determine their pathogenicity could have improved the study. In retrospect, more virulence genes could have been screened and positive controls for all 12 genes studied could have been used.

\section{Recommendations}

Screening for more virulence factors using a larger sample size could provide more definite conclusions. Also, a pathogenicity test of isolates using the 1-day-old chick lethality test to correlate virulence profiles with pathogenicity is recommended. It might be interesting to study APEC from other poultry sources like ducks, geese and turkeys to determine relationships with APEC-causing colibacillosis in chickens.

\section{Conclusion}

The study revealed that the virulence profiles of Zimbabwean APEC isolates may be different from those reported in other studies, which generally show a high prevalence of the virulence genes we investigated in APEC isolates causing colibacillosis in poultry (Ewers et al. 2007; Johnson et al. 2008; Kafshdouzan et al. 2013). This suggests that other virulence genes not investigated in the present study may be important in virulence of Zimbabwean APEC isolates or, more likely, that these isolates are less pathogenic and rely on environmental factors and stress in hosts to establish infection.

\section{Acknowledgements}

The authors thank the CVL, Bulawayo for provision of isolates, especially Zwelabo Sibanda. Special thanks go to the International Network for the Availability of Scientific Publications (INASP) for their assistance through AuthorAID. The study was supported by the NUST Research Board.

\section{Competing interests}

The authors declare that they have no financial or personal relationship(s) which may have inappropriately influenced them in writing this article.

\section{Authors' contributions}

J.M. (NUST) was responsible for the project design, was the principle supervisor and carried out experimental work on the project. Y.O.N. (NUST) carried out experimental work on the project and assisted J.M. in aspects of the project relating to laboratory work. Both authors contributed to writing this article.

\section{References}

Barnes, H.J., Nolan, L.K. \& Vaillancourt, J.F., 2008, 'Colibacilliosis', in Y.M Saif \& A.M Fadly (eds.), Diseases of poultry, pp. 691-732, Blackwell, Ames.

Barrow, G.I. \& Feltham, R.K.A., 1993, Steel's manual for the identification of medical bacteria, 3rd edn., Cambridge University Press, Cambridge. http://dx.doi. org/10.1017/CBO9780511527104

Cavard, D. \& Lazdunski, C., 1990, 'Colicin cleavage by ompT protease during both entry into and release from Escherichia coli cells', Journal of Bacteriology 172, 648-652.

Clarke, B.R., Pearce, R. \& Roberts, I.S., 1999, 'Genetic organization of the Escherichic coli K10 capsule gene cluster: Identification and characterization of two conserved regions in group III capsule gene clusters encoding polysaccharide transport functions', Journal of Bacteriology 181, 2279-2285.

Delicato, E.R., De Brito, B.G., Gaziri, L.C.J. \& Vidotto, M.C., 2003, 'Virulence-associated genes in Escherichia coli isolates from poultry with colibacillosis', Veterinary Microbiology 94, 97-103. http://dx.doi.org/10.1016/S0378-1135(03)00076-2

Dho-Moulin, M. \& Fairbrother, J.M., 1999, 'Avian pathogenic Escherichia coli (APEC)', Veterinary Research 30, 299-316.

Dziva, F. \& Stevens, M.P., 2008, 'Colibacillosis in poultry: Unravelling the molecular basis of virulence of avian pathogenic Escherichia coli in their natural hosts', Avian Pathology 37(4), 355-366. http://dx.doi.org/10.1080/03079450802216652

Ewers, C., Janssen, T. \& Wieler, L.H., 2003, 'Avian pathogenic E. coli (APEC)', Berliner und Münchener Tierärztliche Wochenschrift 116, 381-395.

Ewers, C., Janssen, T., Kiessling, S., Philipp, H.C. \& Wieler, L.H., 2005, 'Rapid detection of virulence-associated genes in avian pathogenic Escherichia coli by multiplex polymerase chain reaction', Avian Diseases 49(2), 269-273. http://dx.doi. polymerase chain reaction
org/10.1637/7293-102604R

Ewers, C., Li, G., Wilking, H., Kiessling, S., Alt, K., Antão, E.M. et al., 2007, 'Avian pathogenic, uropathogenic, and newborn meningitis-causing Escherichia coli: How closely related are they?', International Journal of Medical Microbiology 297 163-176. http://dx.doi.org/10.1016/j.ijmm.2007.01.003

Herren, C., Mitra, A., Palaniyandi, S.K., Coleman, A., Elankumaran, S. \& Mukhopadhyay, S., 2006, 'The barA-uvrY two-component system regulates virulence in avian pathogenic Escherichia coli 078:K80:H9', Infection and Immunity 74, 4900-4909. http://dx.doi.org/10.1128/IAl.00412-06

Jin, W., Zheng, Z., Zhang, Y., Qin, A., Shao, H., Liu, Y. et al., 2008, 'Distribution of virulence-associated genes of avian pathogenic Escherichia coli isolates in China' Agricultural Sciences in China 7(12), 1511-1515. http://dx.doi.org/10.1016/ S1671-2927(08)60410-1

Johnson, T.J., Siek, K.E., Johnson, S.J. \& Nolan, L.K., 2006, 'DNA sequence of a ColV plasmid and prevalence of selected plasmid-encoded virulence genes among avian Escherichia coli strains', Journal of Bacteriology 188, 745-758. http://dx.doi. org/10.1128/JB.188.2.745-758.2006

Johnson, T.J., Wannemuehler, Y., Doetkott, C., Johnson, S.J., Rosenberger, S.C. \& Nolan, L.K., 2008, 'Identification of minimal predictors of avian pathogenic Escherichia coli virulence for use as a rapid diagnostic tool', Journal of Clinical Microbiology 46, 3987-3996. http://dx.doi.org/10.1128/JCM.00816-08

Kafshdouzan, K., Salehi, T.Z., Nayeri, B., Madadgar, O., Yamasaki, S., Hinenoya, A. et al., 2013, 'Distribution of virulence associated genes in isolated Escherichia coli from avian colibacillosis', Iranian Journal of Veterinary Medicine 7(1), 1-6.

Lamarche, M.G., Dozois, C.M., Daigle, F., Caza, M., Curtiss, R., Dubreuil, J.D. et al., 2005, 'Inactivation of pst system reduces the virulence of an avian pathogenic Escherichia coli 078 strain', Infection and Immunity 73, 4138-4145. http://dx.doi. org/10.1128/IAI.73.7.4138-4145.2005 
Li, G., Laturnus, C., Ewers, C. \& Wieler, L.H., 2005, 'Identification of genes required for avian Escherichia coli septicemia by signature-tagged mutagenesis', Infection and avian Escherichia coli septicemia by signature-tagged mutagenesis', Infection and
Immunity 73(5), 2818-2827. http://dx.doi.org/10.1128/IAl.73.5.2818-2827.2005

Maturana, V.G., De Pace, F., Carlos, C., Pires, M.M., De Campos, T.A., Nakazato, G. et al., 2011, 'Subpathotypes of avian pathogenic Escherichia coli (APEC) exist as defined by their syndromes and virulence traits', Open Microbiology Journal 5 , 55-64. http://dx.doi.org/10.2174/1874285801105010055

Mellata, M., Dho-Moulin, M., Dozois, C.M., Curtiss, R., Brown, P.K., Arnè, P. et al., 2003, 'Role of virulence factors in resistance of avian pathogenic Escherichia coli to serum and in pathogenicity', Infection and Immunity 71, 536-540. http:// dx.doi.org/10.1128/IAl.71.1.536-540.2003

Mellata, M., Touchman, J.W. \& Curtiss, R., 2009, 'Full sequence and comparative analysis of the plasmid pAPEC-1 of avian pathogenic E. coli chi7122 (O78:K80:H9)', PLoS One 4, e4232. http://dx.doi.org/10.1371/journal.pone.0004232

Morales, C., Lee, M.D., Hofacre, C. \& Maurer, J.J., 2004, 'Detection of a novel virulence gene and a Salmonella virulence homologue among Escherichia coli isolated from broiler chickens', Foodborne Pathogens and Disease 1, 160-165. http://dx.doi. org/10.1089/fpd.2004.1.160

Olsen, R.H., Christensen, H. \& Bisgaard, M., 2012, 'Comparative genomics of multiple plasmids from APEC associated with clonal outbreaks demonstrate major similarities and identifies several potential vaccine-targets', Veterinary Microbiology 158, 384-393. http://dx.doi.org/10.1016/j.vetmic.2012.03.008

Omer, M.M., Abusalab, S.M., Gumaa, M.M., Mulla, S.A., Omer, E.A., Jeddah, I.E. et al., 2010, 'Outbreak of colibacillosis among broiler and layer flocks in intensive and semi intensive poultry farms in Kassala State, Eastern Sudan', Asian Journal of Poultry Science 4(4), 173-181. http://dx.doi.org/10.3923/ ajpsaj.2010.173.181

Parreira, R.V. \& Gyles, L.C., 2003, 'A novel pathogenicity island integrated adjacent to the thrW tRNA gene of avian pathogenic Escherichia coli encodes a vacuolatin autotransporter toxin', Infection and Immunity 71(9), 5087-5096. http://dx.doi. org/10.1128/IAI.71.9.5087-5096.2003

Pass, M.A., Odedra, R. \& Batt, R.M., 2000, 'Multiplex PCRs for identification of Escherichic coli virulence genes', Journal of Clinical Microbiology 38(5), 2001-2004.

Randall, L., Wua, G., Phillips, N., Coldham, N., Mevius, D. \& Teale, C., 2012, 'Virulence genes in blaCTX-M Escherichia coli isolates from chickens and humans', Research in Veterinary Science 93, 23-27. http://dx.doi.org/10.1016/j.rvsc.2011.06.016

Rodriguez-Siek, K.E., Giddings, C.W., Doetkott, C., Johnson, T.J., Fakhr, M.K. \& Nolan, L.K., 2005, 'Comparison of Escherichia coli isolates implicated in human
urinary tract infection and avian colibacillosis', Microbiology 151, 2097-2110. urinary tract infection and avian colibacillo
$\mathrm{http}: / / \mathrm{dx}$.doi.org/10.1099/mic.0.27499-0

Rouquet, G., Porcheron, G., Barra, C., Répérant, M., Chanteloup, K.N., Schouler, C. et al. 2009, 'A metabolic operon in extraintestinal pathogenic Escherichia coli promotes fitness under stressful conditions and invasion of eukaryotic cells', Journal of Bacteriology 191(13), 4427-4440. http://dx.doi.org/10.1128/JB.00103-09
Sabri, M., Caza, M., Proulx, J., Lymberopoulos, M.H., Brée, A., Moulin-Schouleur, M. et al., 2008, 'Contribution of the SitABCD, MntH, and FeoB metal transporters to the virulence of avian pathogenic Escherichia coli 078 strain $\times 7122$ ', Infection and Immunity 76, 601-611. http://dx.doi.org/10.1128/IAl.00789-07

Sabri, M., Léveillé, S. \& Dozois, M.C., 2006, 'A SitABCD homologue from an avian pathogenic Escherichia coli strain mediates transport of iron and manganese and resistance to hydrogen peroxide', Microbiology 152, 745-758. http://dx.doi. org $/ 10.1099 /$ mic.0.28682-0

Saidi, B., Mafirakureva, P. \& Mbanga, J., 2013, 'Antimicrobial resistance of Escherichia coli isolated from chickens with colibacillosis in and around Harare, Zimbabwe' Avian Diseases 57(1), 152-154. http://dx.doi.org/10.1637/10325-081512-Case.1

Sambrook, J. \& Russell, D.W., 2001, Molecular cloning: A laboratory manual, 3rd edn., Cold Spring Harbor Laboratory Press, Cold Spring Harbor, New York.

Schierack, P., Steinrück, H., Kleta, S. \& Vahjen, W., 2006, 'Virulence factor gene profiles of Escherichia coli isolates from clinically healthy pigs', Applied and Environmenta Microbiology 72(10), 6680-6686. http://dx.doi.org/10.1128/AEM.02952-05

Schouler, C., Koffmann, F., Amory, C., Leroy-Setrin, S. \& Moulin-Schouleur, M., 2004 'Genomic subtraction for the identification of putative new virulence factors of 'Genomic subtraction for the identification of putative new virulence factors of 2973-2984. http://dx.doi.org/10.1099/mic.0.27261-0

Schouler, C., Schaeffer, B., Brée, A., Mora, A., Dahbi, G., Biet, F. et al., 2012, 'Diagnostic strategy for identifying avian pathogenic Escherichia coli based on four patterns of virulence genes', Journal of Clinical Microbiology 50(5), 1673-1678. http://dx.doi. org/10.1128/JCM.05057-11

Sharada, R., Ruban, S.W. \& Thiyageeswaran, M., 2009, 'Antibiotic resistance pattern of Escherichia coli isolated from poultry in Bangalore', Internet Journal of Microbiology 7(1).

Skyberg, J.A., Johnson, T.J., Johnson, J.R., Clabots, C., Logue, C.A. \& Nolan, L.K., 2006 'Acquisition of avian pathogenic Escherichia coli plasmids by a commensal E. coli isolate enhances its abilities to kill chicken embryos, grow in human urine, and colonize the murine kidney', Infection and Immunity 74, 6287-6292. http://dx.doi. org/10.1128/IAl.00363-06

Van der Westhuizen, A.W. \& Bragg, R.R., 2012, 'Multiplex polymerase chain reaction for screening avian pathogenic Escherichia coli for virulence genes', Avian Pathology 41(1), 33-40. http://dx.doi.org/10.1080/03079457.2011.631982

Vandekerchove, D., Vandemaele, F., Adriaensen, C., Zaleska, M., Hernalsteens, J.P., De Baets, L. et al., 2005, 'Virulence-associated traits in avian Escherichia coli: Comparison between isolates from colibacillosis-affected and clinically healthy layer flocks' Veterinary Microbiology 108, 75-87. http://dx.doi.org/10.1016/j.vetmic.2005.02.009

Williams, P.H. \& Warner, P.J., 1980, 'ColV plasmid-mediated, colicin V independent iron uptake system of invasive strains of Escherichia coli', Infection and Immunity 29, 411-416.

Zakeri, A. \&. Kashefi, P., 2012, 'Antimicrobial susceptibilities of avian Escherichia coli isolates in Tabriz, Iran', African Journal of Biotechnology 11(19), 4467-4470. 


\section{Appendix 1}

TABLE A1: Primers used for amplifying regions in avian pathogenic Escherichia coli virulence genes.

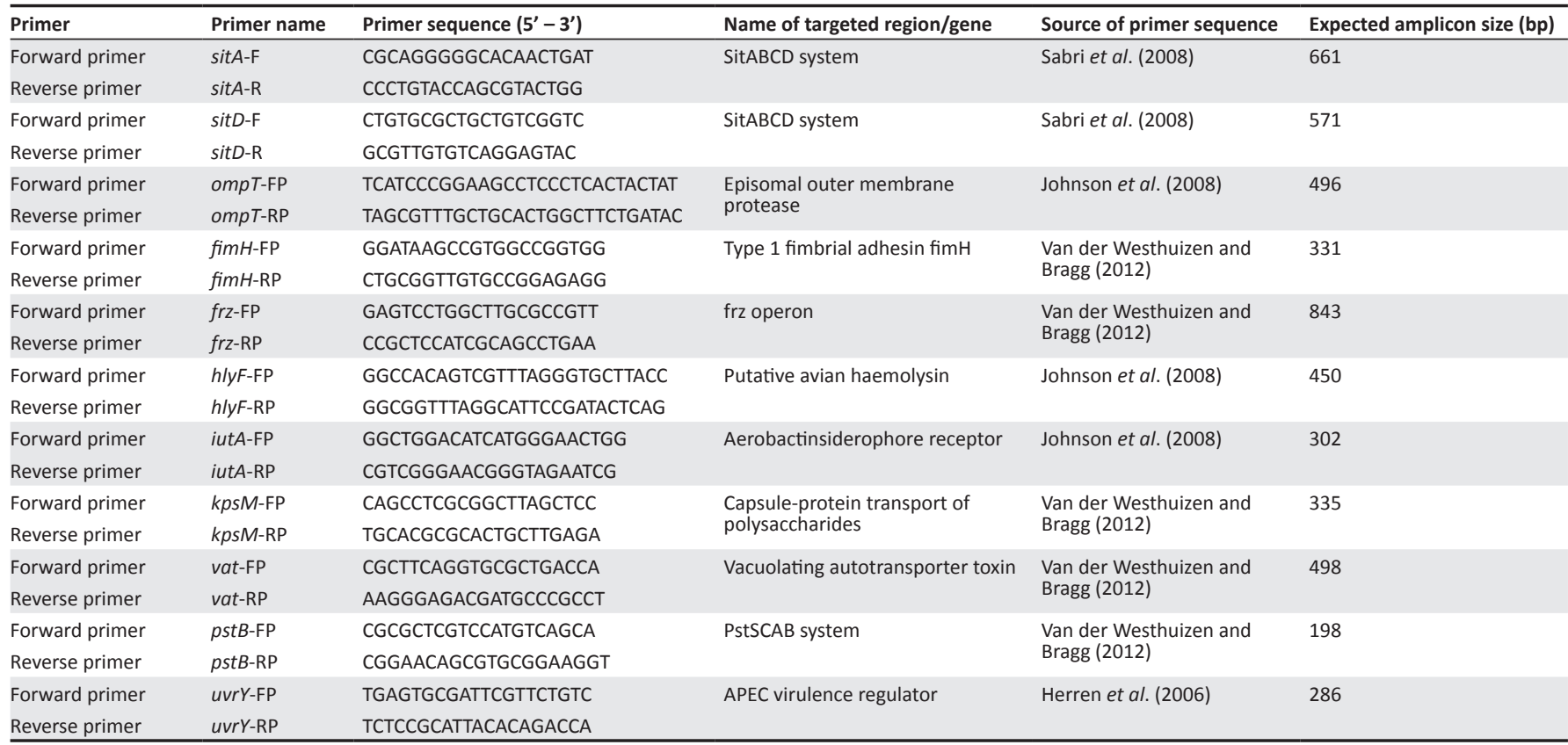

Note: Please see the full reference list of the article Mbanga, J. \& Nyararai, Y.O., 2015, 'Virulence gene profiles of avian pathogenic Escherichia coli isolated from chickens with colibacillosis in Bulawayo, Zimbabwe', Onderstepoort Journal of Veterinary Research 82(1), Art. \#850, 8 pages. http://dx.doi.org/10.4102/ojvr.v82i1.850, for more information. 